\title{
The Perils of Global Cultural Promotion: (Re-)Presenting "European Culture" in Asia through Spanish Cultural Promotion in the Philippines
}

\author{
By José Miguel Díaz Rodríguez*
}

For the last few decades, European cultural organisations such as the Alliance Française de Manille, the British Council, the German Goethe-Institut, and the Spanish Instituto Cervantes have been working actively in the Philippines by establishing and promoting a whole range of cultural and educational activities, related to their particular languages and cultures. In the Philippines, the fact that arts funding is limited, has encouraged the development of a web of intercultural relationships and encounters. This article examines two problematic aspects of the global promotion of Spanish culture in the Philippines, namely the unidirectional approach to cultural promotion, and the politics of arts funding. Inspired by Anthony Giddens' understanding of globalization as a web of distant relationships, in which local events can be influenced by others occurring miles away, the concept of "rough cultural promotion" is proposed to discuss the unidirectional movement of cultural products. When European countries, such as Spain, select and promote specific cultural products as 'universal' referents of "Spanish (or national) culture" in the Philippines, "rough promotion" is achieved. This paper argues that this process establishes several disjunctures in both countries, such as the perpetuation of cultural stereotypes, and an imbalanced situation in which European cultural events are in direct competition with local arts. This imbalanced situation is further explained by exploring the politics of European arts funding in the Philippines. In this context, and following Pierre Bourdieu's theory of cultural production, this paper argues that Spanish cultural producers in the Philippines are establishing an authority in the definition of what arts and culture should be in the Philippines.

Keywords: Philippines, Spain, Asia, Europe, Cultural Relationships, Cultural Promotion, European Promotion, Arts Funding

\section{Introduction}

The typhoon season in the Philippines, which coincides with roughly the period September-December, brings a lot of rain to the Asian country. If you happen to be in Manila, with high levels of humidity and the possibility of getting soaking wet, it is always a safe option to stay indoors and enjoy the many cultural options that the capital has to offer. However, if you are looking for a Filipino show, it sometimes may be tricky for you to find one. Perhaps you can go to the Greenbelt 4 theatre in Makati to see if the latest play that

${ }^{*}$ Lecturer, Massey University, New Zealand. 
Repertory Philippines is showing or you can check whether the CCP (Cultural Center of the Philippines) has one of the national theatre and dance companies as part of its current programme. There is, however, the possibility of attending some European cultural events. In September you can enjoy the many films shown during Cine Europa, the European Film Festival in the Philippines, which is held once a year. Cine Europa, which is organised by the Commission of the EU in Manila and the Embassies of the participating European countries, has been a very popular festival since its first edition in 1998.

Every October you can also watch a Spanish show or movie. Perhaps you might want to attend the Oktoberfest, the German festival, which is also held in October. The cosmopolitan side of Manila does not end during the rainy season, though, as many international events can be enjoyed throughout the year, thanks to the many international organisations that have a Philippine branch, and which organise a whole range of cultural events to promote their arts and culture. In most of these cases, the main objective of this cultural activity is to promote the particular European country in the Philippines. Focusing on Europe, four major organisations are visible and prominent in the Philippines' cultural life: the Alliance Française de Manille (founded in 1920), the British Council (active in the Philippines since 1980), the German GoetheInstitut (which in 2011 celebrated its $50^{\text {th }}$ anniversary in the Philippines), and the Spanish Instituto Cervantes (founded in 1994, but present in the Philippines before this date as the Spanish Cultural Centre since 1972). These institutions share similar interests in the way that all of them focus on the promotion of their own European language and culture. In some cases, this "unidirectional" cultural promotion has led to the promotion and perpetuation of cultural stereotypes that can undermine the "contemporary" approach to cultural promotion overseas, sought by governmental agencies of some countries, such as Spain.

Another common element that the European institutes share, is their expenditure on funding of local artists and, to some extent (depending on the particular organisation), the investment on local arts. In the Philippines, where there is limited local funding for cultural activities, many of the local artists and companies decide to fit their art works into a foreign agenda, so as to have enough funding to make them happen. Apart from funding reasons, European cultural activities in the Philippines have a good reputation and, therefore, when Filipino artists are funded by European institutions, they acquire certain values and can be perceived as gaining international recognition, by aligning themselves with these reputable institutions.

Focusing on the Spanish case, this article examines these important issues in Spanish cultural promotion in the Philippines during the first decade of the $21^{\text {st }}$ Century. This period is especially relevant as it represents a time when there was a conscious decision from the Spanish government to follow specific strategic plans to promote Spain in Asia, and the Philippines in particular (due to the historical connections between the two countries). The first Framework Plan (MAE, 2000) was launched in 2000, and it was followed by the Action Plan in 2005 (MAEC, 2005), which was updated in the Plan Asia 3 in 2009 
(MAEC, 2009). The implementation of these plans meant, among other things, an intensification of the cultural activities organised by Spanish institutions in the Philippines, as well as an increase in Spanish funding of local events that were in line with the objectives established in the plans. Furthermore, the relevance of this legal framework in Spanish-Philippine cultural relationships lies in the fact that the Philippines was listed as a priority for Spanish foreign affairs in the Plan Asia 2005-08 (MAEC, 2005, p. 121). Also, the Plan 3 explains that the Spanish Government's intention was to deepen bilateral political and cultural relationships, which had greatly increased since 2005 (MAEC, 2009, p. 41).

Considering the importance of these legal documents, this article analyses several aspects of Spanish cultural policy as described in the three official plans, in order to understand the Spanish approach to cultural promotion in the Philippines, and some of its consequences for the Philippine arts scene. Contextualising the study of these documents, many examples of cultural events are also described as to offer a wider view of the implementation of Spanish cultural policies in the Philippines. Following Pierre Bourdieu's theory of cultural production $(1993 ; 1998)$, concepts such as 'distinction', 'field of power' and 'cultural capital' have been used to analyse the situation. Further data was collected in two in-depth interviews that I conducted in 2010 and 2011 with two of the local cultural workers who were involved in the organisation of many of the cultural events at the Instituto Cervantes, during the period studied in this article. This information was extremely useful as it added different perspectives to the implementation of Spanish cultural policy.

The main argument is that Spanish official cultural policy (in relation to the Philippines) primarily follows a unidirectional approach to the promotion of "culture". This poses some "perils" for those countries involved, such as the perpetuation of cultural stereotypes. Furthermore, this article argues that Spanish funding programmes in the Philippines in general, and particularly those led by Spanish institutions, can be understood as being immersed in a 'field of power' (Bourdieu, 1998), in which certain European cultural organisations that are based in the Philippines (such as the Spanish Instituto Cervantes, or the Embassy of Spain) possess high amounts of cultural capital and may 'dominate', at times, the cultural scene in Manila. Moreover, by funding selected Filipino arts, the Spanish cultural producers claim an authority in terms of arts and culture, and establish specific markers of distinction, which act as classifiers of 'taste' and, ultimately, define what is to be considered as 'artistic' or worthy. In many ways, these Spanish statements of authority in the Philippines echo the historical relationship between both countries, as the Spanish government aims to establish some kind of cultural influence over the Philippines. This is something that already happened during the Spanish colonial rule of the Philippines. 


\section{Colonial Legacies in the Philippines}

Spanish colonisation of the Philippine Islands spanned over three centuries and ended formally in 1898, when the United States took control over the islands through different administrative systems until 1946. Both imperialist periods left indelible imprints in the country, a theme that is recurrent in contemporary Philippine cultural studies. Some Filipino scholars have discussed the consequences of colonialism in the Philippines. For instance, Fernando Zialcita asserts that the 'Philippines has been dominated by foreign powers, and continues to be so today' (Zialcita, 2005, p. 19). Furthermore, he explains that 'almost any major problem of the Filipino today is attributed to colonial influence, particularly the Spanish' (Zialcita, 2005, p. 11), and he adds that in the Philippines there is still 'a claim that all Spanish influence is evil' (Ibid., p. 23).

One of the most influential contemporary Filipino writers, Sionil José, affirms that 'colonialism (...) persists in actual forces of domination, control [and] a virus in the mind' (Sionil, 2008, p. 177), described as 'the feelings of inferiority, of helplessness and apathy in the colonized' (Ibid.). Moreover, he asserts that the country is also 'colonized' by its own rulers (Ibid., p. 178). Another example of postcolonial criticism is Filipino scholar Priscelina PatajoLegasto, who believes that Philippine studies should make inquiries 'to liberate [Filipinos] from the legacies of Spanish and American colonialist discourses and the continuing power of Western hegemony' (Patajo-Legasto, 2008, p. XXIII). This definition indicates that the Spanish colonial period is a sensitive topic in contemporary Philippines, and can be framed in a postcolonial context as a critical review of colonial relationships as well as their repercussions. Considering all of these Filipino perceptions on the consequences of Spanish colonialism, the new thrust in Spanish cultural promotion in the Philippines in the new Millennium can pose some challenges for Spanish arts managers.

Despite this context, at the turn of the century it was decided in Spain that cultural relationships with the Philippines were to grow and flourish. A hundred years after the end of the colonial relationship with the Philippines, Spain presented itself, once more, as a leading country in Spanish-Filipino cultural relationships. It had the impulse, the official backing and the economic and human resources to re-establish cultural relationships with the Philippines.

\section{Spanish official Cultural Promotion in the Philippines}

In 2000, the Spanish Ministry of Foreign Affairs published its first major strategic plan to reach out to Asia. The Framework Plan aimed to tackle a number of foreign affairs issues, such as the lack of a Spanish official unified policy towards this area, as well as the overall absence that Spain had in the region in terms of economic, cultural and diplomatic relationships. This document was followed by the 2005 Action Plan, and the 2009 Plan Asia 3. These plans, which mentioned specific policies on Spanish cultural promotion 
in Asia, clearly defined the Spanish presence in Asia within a European dimension. Since Spain became a member of the EU in 1986, its foreign policy has been adapted to suit the European project, which was "key" for Spain to develop a new policy towards Asia' (De Prado Yepes, 2005, p. 31). In the 2005 Spanish Action Plan, the contextualisation of Spain within European frameworks is referred to as a strategic tool in Spanish-Asian political relations:

In the case of our [Spanish] relationships with Asia, the membership to the EU is already a relevant factor which allows us to articulate a greater presence in the existing forums and take advantage of the Union's instruments to further a bilateral strategy.

(MAEC, 2005, p. 167)

The strong European focus in the 2005 plan is related to a shift in Spanish foreign policies that followed the change in government in 2004. Prior to this, 'the Aznar government (...) aimed at aligning the country closely to the United States' (García Pérez, 2003, p. 547), even though the government encountered certain opposition from some of the EU members, at least until the 2001 terrorist attacks, which marked a closer relationship of the EU and the US (Ibid., p. 547). From 2004, the Zapatero government shifted the focus from the US to Europe. Following this idea, Spain has participated periodically in many events that the European Commission office in Manila has organised in the Philippines, such as the May celebrations named as Europe Month. These activities follow the EU's objective of constructing and promoting people's awareness of a 'European Identity' as opposed to 'the non-European other', a task that has been part of the European Commission's cultural policy since the mid-80s (Shore, 1993). Adding the European dimension to Spanish foreign policies can be read as a way for Spain to raise its international profile and align itself with a 'European identity', which is more relevant in Asia than the idea of Spain by itself. This 'European strategy' makes Spain more visible in Asia.

Apart from participating in European events, Spanish official institutions in the Philippines have also organised their own cultural events. Carefully laid out in the three official Spanish plans to reach out to Asia, and backed up by an infrastructure consisting of human and economic resources, the number of Spanish cultural events in the Philippines increased dramatically for the period 2000-2012 (from 10 to 35 events, according to Embassy staff). This means that since the approval of the 2000 plan, there has been a steady increase in Spanish cultural production in the Philippines. The broad goal in all of these events has been the promotion of 'Spanish arts and culture', with no direct connection to the host country. I am referring to arts events such as 'Pelikula' (the Spanish Film Festival in the Philippines), flamenco shows ('Seis cuerdas para dos tacones' in 2010, 'El flamenco de Arcángel' in 2009, Aída Gómez's 'Carmen' in 2006, Lola Greco's 'Iberia' in 2008, Sara Baras' flamenco company in 2005), contemporary dance (Provisional Danza's 'The Sky in my pocket' in 
2008, Jordi Cortés and Damián Muñoz's 'Ölelés' in 2006, Aukeran's 'The Magic of Spanish Dance' in 2004), exhibitions ('A Portrait of Spain' in 2011, '150 Years of Photography in Spain' in 2006), and music concerts (Jorge Orozco in 2005, 'A Night of Spanish Guitar' in 2004).

This unidirectional promotion of selected arts events can be read in several ways. First, it expands the arts scene in the Philippines, by entering the field of cultural production (Bourdieu, 1993) in the Asian country; second, it establishes an authority about which arts and cultural events are considered as worthy, and third, it provides a range of selected cultural works that are presented as representative of Spain and Spanish culture. In this context, it can be argued that 'Spanish culture' is perceived by the official cultural producers as 'distinctive', as the Spanish cultural organisations aimed to offer selected examples of contemporary Spanish arts, and, in turn, different to arts events from other countries. The concept of 'distinction' that I used to analyse this situation was defined by Bourdieu as:

To occupy a point (...) to differ, to be different (...) Difference becomes a sign of distinction (or vulgarity) only if a principle of vision and division is applied to it which, being the product of the incorporation of the structure of objective differences (...) is present among all the agents (...) and structures the perception.

(Bourdieu, 1998, p. 9)

This search for distinction is a feature of Spanish foreign affairs policies related to cultural promotion and exchanges over the last decade. Even though there was a change in government and a consequent shift in Spanish politics (from right to left) in 2004, the perception of Spanish language and culture as prestigious and powerful are important elements of the legal discourse in the three Spanish plans to reach to Asia. As early as 2000, the Framework Plan focused on cultural promotion, articulating the idea of distinction in its major objective, described as:

The promotion of Spanish culture, taking advantage of its capability to transmit a prestigious image of Spain, thanks to the quality, dynamism and recognition, growing every day, of its current creators (mainly in cinema, fine arts and performing arts) as well as the singularity and excellence of our artistic and cultural heritage.

(MAE, 2000, p. 8)

Spanish culture is described in relation to particular values, perceived as positive, such as 'quality' and 'dynamism', but more importantly, it is believed to be 'singular' and, therefore, an asset which helps the European country's promotion in Asia. Similarly, the Plan Asia 2005 perceives Spanish culture as distinctive: 
In the cultural area, we [Spain] already have an irrefutable advantage which is provided by the universality of our culture, even when we [Spain] cannot count on the same levels of cultural infrastructure as other countries.

(MAEC, 2005, p. 144)

This statement is very interesting as it offers some insights into the way that 'Spanish culture' is perceived by the Spanish government. There is an acknowledgment that Spanish cultural infrastructure in Asia cannot compare to that of other countries, due to the low attention that was given to the Asian region by Spain prior to 2000 (MAE 2000). However, this situation is outweighed by the perception of Spanish culture as 'universal'. In this case, 'universal' can be understood not only as differential, but also as internationally well-known and reputable. It is described in the legal documents as immersed in some kind of international 'symbolic capital', which is already wide spread. Following this idea, the Plan Asia 3 (2009) explains that:

The demand for Spanish language and anything Spanish in Asia is increasing, which will benefit the dissemination of our language and culture (including Latin American), as well as the promotion of our cultural industries, mainly the editorial and audio-visual.

(MAEC, 2009, p.14)

These lines describe some strategic advantages for Spanish cultural products to be promoted in Asia. At the same time, this statement is part of a discourse of difference, as 'anything Spanish' constitutes a category which is recognisable by the Spanish Government, and also believed to be recognisable in Asia. It is within this understanding that many of the Spanish cultural activities were organised in the Philippines in the first decade of the new millennium. An example of these activities was 'Fiesta', the Spanish Arts Festival, which was held in Manila every year from 2001 to 2009, combined with 'Pelikula' (the Spanish and Latin American film festival), and organised by the Instituto Cervantes. In an interview that I held with Isabel García, an arts administrator who helped organise this festival every year, she mentioned that:

... [i]t seemed that the festival formula worked for Manila. It continued for a few years, very successfully, every year it got better and better, also because of the funding from the Embassy (...) The headquarters in Madrid took notice and started sending more events. But the difference was that there was less interaction. It was more like Spain was sending everything and Filipinos were just being the audience. [García, 2011, interview]

García goes deeper in the issue of unidirectional cultural promotion by comparing the situation in the first few editions of the festival in contrast to 
later ones. She explains that in the first few editions, there was a stronger connection to the Filipino public, because the festival was initially created and organised in Manila by a team of Spaniards and Filipinos, who were in situ and tried to make it fit into the Manila cultural scene. However, in later editions, there was a bigger input from those arts managers based in Madrid. This is an extremely important aspect of Spanish (and in some cases European) cultural promotion in the Philippines. Cultural events are thought out and organised in Spain, following the philosophy and objectives of Spanish institutions, and so there is a disjuncture or disconnection between the original cultural producers (in Spain) and the final reception, which takes place in the Philippines. I would label these events as 'rough cultural promotion' as they are initially envisioned without a real context of reception. They can be sent to any country in the world because they are considered as 'universal' referents of Spanish culture regardless of the connections or possible consequences of reception in the receiving country. As Isabel García suggests, this unidirectional flow of culture makes those on the receiving end more passive, feeling that they are 'just the audience', with no hope of interaction. This inward-looking perception of cultural production can be risky, and even counteractive, for the cultural producers, the Spanish authorities in this case. The act of sending proposals and suggestions for cultural activities by the central offices becomes a way to define, produce and promote several representations of constructs such as 'Spain', 'Spaniards', and 'Spanish culture'. The selection process can fall in self-stereotyping, which, in this context is a double-edge sword. On the one hand, it makes it easier for those who are on the receiving end to understand those definitions, as they are already categorised into simple, stereotyped contents. On the other hand, as Michael Pickering (2001) points out, there is another side to this process as stereotyping:

... always occurs at a cost to those who are stereotyped, for they are then fixed into a marginal position or subordinate status and judged accordingly, regardless of the inaccuracies that are involved in the stereotypical description given of them.

(Pickering, 2001, p. 5)

By producing and promoting selected representations of 'Spanish culture' through the organisation of events, Spanish cultural producers can fall into the trap of legitimising and continuing stereotypical contents that might not be in line with the objectives set in the Spanish official plans. As the Spanish strategic plans to reach out to Asia mention, if one of the objectives of Spanish cultural promotion abroad is to communicate a 'contemporary' image of Spain, stereotyped images might not be the best way to achieve it. An example of the use of stereotyped content is the common images that come to mind to some Filipinos when thinking of Spain. When asked about the perception of the objectives of Spanish cultural policy abroad, and in the Philippines in particular, Filipino artist Stephanie Palallos (who worked at the Instituto 
Cervantes on a project basis for a few years) states that through the cultural activities, Spanish institutions:

... promote Spanish culture: 'flamenco', 'paella', 'vino'... the usual things that first come to mind when you think of 'Spanish'... it is a very traditional approach. At the time [in 2001] there wasn't any attempt to work with Filipino artists.

[Palallos, 2011, interview]

In fact, as Palallos explains, many of the cultural activities in the Spanish Arts Festival followed this pattern. Some examples include the big flamenco shows, the street party events in which a huge paella (selected as representative of Spanish food) was cooked outdoors, and where there was wine, music and dancing. The repetitive use of stereotypical content and the constant references to 'Spanishness' in parts of the programmes of Spanish cultural promotion in the Philippines was not unnoticed, and the selection process was challenged by those who, like Palallos, have experienced a wide range of Spanish arts:

It's all one-sided; it's all about what is 'Spanish'. It's also repetitive. It doesn't reflect what's happening in Spain. I have lived in Spain, so I know they could do so many different things, but they only give you a limited selection of Spanish arts and culture.

[Palallos, 2011, interview]

The stereotypical production of selected Spanish cultural products also has to do with official definitions and further production and reproduction of specific representations of national cultures. However, stereotypical production is only one of the perils of this type of transnational cultural promotion, as the politics of European arts funding in Philippines can also establish a set of power relations between those foreign and local parties involved.

\section{The Perils of European Arts Funding in the Philippines}

In a study on cultural policy in Southeast Asia, Jennifer Lindsay (2002) argues that there is a difference between Europe and Southeast Asia in terms of the rationales behind government subsidised arts. In Europe, she explains, 'government subsidy or public money supports cultural forms which are not in themselves fully viable commercially, but these activities are also part of a greater whole' (Lindsay, 2002, p. 73). In Southeast Asia, 'Subsidies are given for reasons of establishing national identity, protection of moral and religious values, and protection of indigenous heritage (material and expressive)' (Ibid., p. 73). However, she further explains that the Philippines and Singapore are the only countries in the region to establish 'a formal advertised system of grants for which individual and independent artists may apply, and where the decision makers for the grant include advisors outside the government' (Ibid., p. 67). 
Even though the official reasons to fund particular projects might be different in Europe (and possibly variable across countries) and in Southeast Asia, it can be argued that the heart of the politics of funding is very similar in both cases.

Every time that a public or government funder opens particular calls for applications, it is defining those arts that are worth funding, and consequently, it is establishing an official version of their arts and culture and, therefore, defining its national 'identity'. The Arts Council in England, for instance, has a continuously open call for applications to fund arts projects. Their slogan is (at the time of writing) Great Arts and Culture for Everyone, which includes a whole set of priorities in terms of what type of activities and arts event are worth funding and who they will fund (not everyone is eligible to apply). In this extremely regulated system, every category to be filled in the application form contains a definition of who, what, where and how arts must be produced. The very few who manage to eventually get funding for their projects, gain economic resources, as much as status, and the art works will then be categorised as 'the best of British art'. In the end, this is as much a representation of a national identity as in the case of Southeast Asian policies. The wording might be different, but the politics of funding follow a similar pattern by establishing definitions of who the funded artist should be, what type or arts should be created, where the arts are to be created and, in many cases, how the cultural activity must be conducted. Finally, the end products are used as representations of national identity, which is often then utilised by the countries in their cultural projections abroad.

Perhaps the major difference between European and Southeast Asian funding policies as a whole is the amount of funding that is available for local arts. Even in 2012, when the EU was already immersed in economic turmoil, there was a level of arts funding available, which cannot compare to the levels available in countries like the Philippines. In this aspect, I agree with Lindsay when she states that:

... foreign funding agencies (...) provide an alternative source of support to artists [in Southeast Asia] and (...) have the advantage of operating in a way that allows them to apply directly (...) The thriving community theatre scene in the Philippines is virtually run on foreign support for example.

(Ibid., pp. 75-76).

It is within this economic context that the situation of official foreign arts funders in the Philippines can be described as powerful, in relation to local Filipino investment. Considering the Spanish case, cultural products are perceived as both a promotional tool for Spain and an instrument for the development of Philippine cultural industries through Spanish economic investment in local arts. These two ideas are followed by the two main cultural producers of Spanish culture in the Philippines: the Instituto Cervantes and the Spanish Embassy. 
Spanish funds for cultural promotion are spent by Spanish institutions in the Philippines on either Spanish or Filipino cultural expertise, such as artists, cultural workers, and art works. These exchanges can be seen in the economic realm, as they follow an exchange of services in the context of the cultural industries. However, the product of those 'economic exchanges' is, most of the time, offered for free to the Filipino audiences, as the Spanish government decided to include these activities in the programmes for cultural cooperation, therefore, not expecting a direct economic return or profit from the activities, but with clear objectives or expectations of creating 'popular activities' that would fill the theatre, the museum or the conference hall, depending on the case. On the other hand, there is also an expectation of influencing in some way the perception or attitudes toward the country that organises the cultural activity. In this regard, cultural policy has become constructive or, in Rudolph's words, 'constitutive' as the arts have had the 'capacity to create and inculcate metaphors of reality, languages for meaning and beauty that shape a nation's world-view and identity' (Rudolph, 1983, p. 12).

Once a cultural activity has been organised, promoted and advertised, it has become part of a general cultural menu of other local cultural activities and its attendance would be in competition with any other activities organised around the same time. Following these ideas, a 'field of power', in Bourdieu's words, has been established. He describes this field as:

The space of the relations of force between the different kinds of capital or, more precisely, between the agents who possess a sufficient amount of one of the different kinds of capital to be in a position to dominate the corresponding field.

(Bourdieu, 1998, p. 34)

In our case, the tension has been created by Spanish cultural producers who have large amounts of both 'symbolic' and 'economic capitals' and are in 'competition' with local cultural products which have very different amounts of economic capital.

However, apart from this disjuncture between local and selected foreign arts events in the Philippines, one step forward in the analysis of Spanish cultural producers as immersed in the cultural and artistic field and, embedded in a power struggle, is the consideration of the connections between Spanish funding policies and the idea of authority. The argument here is that some kind of authority is established by the agenda of arts funding, which in itself, is constantly defining and redefining concepts such as 'the artist' and 'the art work'. In this context, it is useful to reflect on the idea of Spanish cultural production in the Philippines. The yearly cultural programmes run by Spanish institutions in the Philippines can be described as 'cultural capital' that, in this case, is linked to economic capital that comes from Spain and makes it happen. In his study on Bourdieu, Randal Johnson explains that: 
Cultural capital thus participates in the process of domination by legitimizing certain practices as 'naturally' superior to others and by making these practices superior even to those who do not participate. (Bourdieu, 1993, p. 24)

This is clearly understood in the several selection processes that take place in Spanish cultural promotion abroad, in which Spanish cultural institutions based in Spain decide on which aspects of Spanish arts and culture should be selected, and further developed to be sent and promoted overseas. In this process the first definition of the arts has been legitimised. Similarly, the cultural sections of the Embassy of Spain and the Instituto Cervantes in the Philippines decide on what projects are to be part of the cultural programmes. This definition not only affects what is delimiting the 'Spanish cultural work' but, it is also determining what constitutes the 'Filipino cultural work', should there be local artists involved in the cultural programmes. The nature of the relationships between Filipino artists and Spanish institutions is one of authority. It is a relationship in which the rules are set by the Spanish institutions that have the economic resources, as well as the symbolic power, to create and promote their own cultural capital, to which those who want to participate in the cultural events have to agree in principle.

In this context, it can be argued that both "rough cultural promotion" and Spanish funding on Filipino arts, affects and helps establish an unbalanced situation in the Philippine arts scene. In a way, it echoes Anthony Gidden's classic definition of globalisation as:

... an intensification of worldwide social relations which link distant localities in such a way that local happenings are shaped by events occurring many miles away (Giddens, 1993, p. 181).

The argument here is that the end result of Spanish cultural policies in the Philippines, as an organised conglomerate of cultural activities were thought out in a completely different environment to where they were going to be put into practice. However, they still have the power to affect the local Philippine arts and cultural scenes.

\section{Conclusions}

This article started by describing some aspects of recent (2000-2012) Spanish cultural actions in the Philippines, and arguing for a definition of some of their features as "perils" for both countries. The unidirectional promotion of selected arts events was described as serving several functions, such as entering and expanding the field of cultural production in the Philippines, and establishing an authority about which arts and cultural events are considered as worthy. However, these particular representations of "Spanishness" could fall into a trap of perpetuating stereotypes about Spain. Furthermore, the fact that 
most of the activities organised by the Spanish institutions in the Philippines are 'free', together with the ideas of perceived prestige that are connected to European cultural activities, put the cultural programmes in a position of tension in the middle of the web of available cultural options. By offering 'free' cultural events, the country is positioning its cultural products in the realm of the 'symbolic goods' and according to Bourdieu:

Symbolic acts always assume acts of knowledge and recognition, cognitive acts on the part of their recipients. For a symbolic exchange to function, the two parties must have identical categories of perception and appreciation.

(Bourdieu, 1998, p. 100)

In this context, the real effects of the Spanish cultural activities could be very different to those expected, as those categories of perception and appreciation vary considerably across cultures and communities. On the other hand, looking at this issue from the perspective of globalization, the way that the promotional cultural activities influence the recipient country's views and perceptions, is also a problematic issue as different cultural forms and values are not to be implemented within the more 'controlled' (or at least better known) boundaries of the nation-state, but to travel across frontiers with the intention of influencing other cultures, as Diana Crane points out:

As national culture industries extend their activities transnationally, cultural content is likely to become increasingly stereotyped but in turn subject to an ever greater variety of interpretations by increasingly diverse audiences.

(Crane, 1992, p. 172)

The peril here is for the European cultural institutions, which carefully plan their promotional activities overseas, but might encounter that once the activities are organised and conducted, they might have the opposite effect to that intended, by fixing some stereotypical content that can be interpreted in a variety of manners.

\section{References}

Bourdieu, P., 1993. The Field of Cultural Production. Cambridge: Polity Press.

Bourdieu, P., 1998. Practical Reason: On the Theory of Action. Cambridge: Polity Press.

Crane, D., 1992. Foundations of Popular Culture Vol. 1: The Production of Culture: Media and the Urban Arts. Newbury Park: Sage Publications.

De Prado Yepes, C., 2005. The effect of ASEM on European foreign policies. Asia Europe Journal, Issue 3, pp. 25-35. 
Díaz Rodríguez, J. M., 2013. Revisiting Empire: The Poetics and Politics of Spanish Contemporary Representations of the Philippines. PhD Thesis. The University of Leeds.

Elizalde Pérez-Grueso, M. D., 2003. Presentación. In: M. D. Elizalde Pérez-Grueso, ed. Las Relaciones entre España y Filipinas (S. XVI-XX). Madrid-Barcelona: Casa Asia y Consejo Superior de Investigaciones Científicas, pp. 11-13.

García, I., 2011. Interview with I. García in Makati. By: J.M. Díaz Rodríguez. Metro Manila, Philippines.

García Pérez, R., 2003. España en un mundo de cambio: a la búsqueda de la influencia internacional (1986-2002). In: Juan Carlos Pereira. ed. La política exterior de España (1800-2003): Historia, condicionantes y escenarios. Barcelona: Ariel, pp. 539-550.

Giddens, A., 1993. From The Consequences of Modernity. In: L. Chrisman \& P. Williams, eds. Colonial Discourse and Post-Colonial Theory. Harlow: Prentice Hall, pp. 181-189.

Lindsay, J., 2002. A Drama of Change: Cultural Policy in the Performing Arts in South East Asia. In: D. Crane. ed. Global Culture: Media, Arts, Policy and Globalisation. Routledge: New York and London, pp. 63-77.

MAE, Ministerio de Asuntos Exteriores, 2000. Plan Marco Asia Pacífico 2000-2002. Madrid. [pdf] Available from: http://www.casaasia.es/pdf/home_plan_asia_paci fico.pdf [Accessed: January $22^{\text {nd }}, 2009$ ]

MAEC, Ministerio de Asuntos Exteriores y de Cooperación, 2005. España hacia Asia y el Pacífico: Plan de Acción 2005-2008, Madrid. [pdf] Available from: http:// www.casaasia.es/documentos/plan_accion_asia2005.pdf [Accessed: January 22nd, 2009]

MAEC, Ministerio de Asuntos Exteriores y de Cooperación, 2009. Plan Asia Pacífico 3, Madrid. [pdf] Available from: www.relacionesinterna cionales.info/ojs/article/ download/201/183.html [Accessed: November 10th, 2010]

Palallos, S., 2011. Interview with S. Palallos in Manila. By: J.M. Díaz Rodríguez. Metro Manila, Philippines..

Patajo-Legasto, P., ed. 2008. Philippine Studies: Have We gone Beyond St. Louis? Quezon City: University of the Philippines Press, pp. xv-xxiii.

Pickering, M., 2001. Stereotyping: The Politics of Representation. Hampshire and New York: Palgrave.

Rudolph, L.I., 1983. Establishing a Niche for Cultural Policy: An Introduction. Pacific Affairs, 56(1), pp. 5-14.

Shore, C., 1993. Inventing the "People's Europe": Critical Approaches to European Community Cultural Policy. Man: Journal of the Royal Anthropological Institute of Great Britain and Ireland, 28(4), pp. 779-800.

Sionil José, F., 2008. Romancing Colonialism and the Colonized Mind. In: Why We Are Hungry; Rats in the Kitchen, Carabaos in the Garden. Manila: Solidaridad Publishing, pp. 173-178.

Zialcita, F.N., 2005. Authentic Though Not Exotic: Essays on Filipino Identity. Quezon City: Ateneo de Manila University Press. 